\title{
Attitude Dimensions and Shopping Mall Purchasing
}

\begin{abstract}
The concept of attitude has been one of the main concept used to explain individual differences. The main objective of the study was to examine association between attitude dimensions and shopping mall purchasing and to determine the impact of advertising on shopping mall purchasing in Nepalese consumers. The present study is descriptive and analytical in nature. Structured questionnaire technique under survey approach is applied for collecting primary data with five point Likert scale questionnaire. The population of this study targeted the consumers of shopping malls in Kathmandu valley. This sample size has been derived for unknown population that is 384. The judgment sampling technique has been used in this research to make this study more inclusive and representatives. Descriptive statistics and inferential statistics such as correlation analysis and Regression analysis have been used to analyze the data. The study found that the affection and behavior components are positively associated but cognition is negatively associated with shopping mall purchasing. However the study also found that advertisement has no significant impact on shopping mall purchasing.
\end{abstract}

Key words: Attitude dimension, affection, behavior, cognition, shopping mall, advertising

\section{Background of the study}

The concept of attitude is multidimensional and has been one of the main concepts used to explain individual differences, and to understand and predict changes in human behavior. Attitude is widely used in many fields, it has been called the most distinctive and indispensable concept in contemporary American social psychology and the consumers' attitude are widely used in the marketing field (Xiao \& He, 2011). Attitudes may simply be an enduring evaluation of a person or object, or other emotional reactions to objects and to people. Attitudes also provide internal cognitions or beliefs and thoughts about people and objects. Attitude is important in marketing because performance in the job depends on personal attitude and attribute. Attitudes help to define how to see situations, as well as define how to behave toward the situation or object (Pickens, n.d.).

An attitude is a point of view, either negative or positive, about an idea, situation, or person. Favorable attitude about those ideas, situation and people there are associated with positive reward and benefit and unfavorable attitude toward those that are associated with penalties

* Faculty of Management Tribhuvan University, Kathmandu, Nepal Email: raju.pyc@gmail.com 
or dislike. An attitude is also an outlook on life or a mind-set about something. Typically, when we refer to a person's attitudes, we are trying to explain his or her behavior (Pickens n.d.).

The shopping mall concept is a big hit with the sole purpose to provide a variety of products under one roof or in one big complex. Consumers seem to be undergoing a shift in terms of personality, buying motives, interests to attitudes, beliefs and values when consumer is making purchase decision shift from 'Kirana' (grocery) stores towards shopping malls(Sharma, 2012). In this context, it is important to study the shopping mall purchase behavior of consumers in Nepal especially with changes taking place in Nepal's retail scenario. Although the shopping mall is getting popular and shopping mall purchase is gradually increasing, consumers' purchase behavior is changing due to the attitude dimensions such as cognition, affection, behavioral and other moderating dimensions like advertising and purpose to visit.

The trend of shopping for goods and groceries has recently been changing in Kathmandu. People have started to shop at the numerous shopping centers rather than going around individual shops and stores. As the people have started to get busy in this fast changing world, the idea of saving time has also made many people for shopping centers opened around the various centers of Kathmandu. Also, the fact that these centers house various products under the same roof has attracted many shoppers to them. Some of the most popular shopping centers in Kathmandu are as follows: Civil mall, Kathmandu mall, United World Trade Center, City center, Kantipur mall, Sherpa mall, K.L. tower, Blue bird mall, People plaza etc. (www.bossnepal.cm/Popular shopping center in Kathmandu-2).

\section{Statement of the problem}

In recent time of consumerism, shopping malls are gradually replacing 'Kirana' stores in major cities of India (Sharma, 2012). In the context of Nepal there is dearth of researches in the field of shopping mall purchasing behavior. A study by Sharma, (2012) in Mumbai, India states that many consumers make their purchases from the local 'Kirana' stores. But recently, Nepal's retail infrastructure is slowly undergoing a change with many shopping malls being constructed and operating in various cities.

The lifestyle of the consumer pervades various aspects of individual's life and varies according to the sociologically relevant variables. Family incomes are seeing a jump in recent times resulting in the consumer spending more and a change in the lifestyle of the consumer is of great interest to society at large, manufacturing and consumer companies, advertisers, super mall owners, economists, census, researchers and so on (Sharma, 2012). 


\section{Research questions}

Hence the present study aims to address the following research questions in the context of Nepal and especially in the area Kathmandu Valley.

1. Is there an association between attitude dimensions and shopping mall purchase?

2. What impact advertising has on shopping mall purchase?

\section{Research objectives}

The major objectives of this study are to explore the association between attitude dimensions and shopping mall purchase behavior. And some of other specific objectives are mentioned bellow.

3. To examine the association of attitude dimensions on shopping mall purchase.

4. To assess the impact of advertising on shopping mall purchase.

\section{Literature review}

Allport (1935) defined an attitude as a mental or neural state of readiness, organized through experience, exerting a directive or dynamic influence on the individual's response to all objects and situations to which it is related.

More specifically, "attitude refers to knowledge and positive or negative feelings about an object or activity" (Pride and Ferrell, 1991) and can also be seen as an "overall evaluation that expresses how much we like or dislike an object, issue, person or action" (Petty, Unnava, and Strathman, 1991 apud Hoyer Macinnis, 2001; Solomon, 2004).

Attitude means a learned predisposition to respond to an object in a consistently favorable or unfavorable way (Jen-Hung Huang et al., 2004).

Marketers use the three components-ABC model to describe consumer's attitude (Sharon Jayson 2004):

- Cognitive component: it refers to consumer's beliefs towards a brand, outlet, product, action and so on. It is based on consumer personal knowledge, actual experience.

- Affective component: it refers to consumer's feelings, such as liking, disliking or feeling neutral about a brand, outlet, product, service and so on. It comes from his or her belief.

- Intention component (behavior or behavioral intention): it refers to consumer's intention to act positively, negatively or neutrally towards the brand, outlet, product service and so on. It comes from his or her affective component stance. Peter and Olson, (2008), to sum up attitude is not the exact forerunners that say which consumption behavior will be in the future but they can show the way what buyers are likely to do in a defined situation (Chisnall , 1995). 
Attitudes are formed by three main components (Hawkins, Best et al. 2004): Cognitive Component, related to the consumer 's beliefs about a product, which can be generally evaluated; Affective Component, related to the feelings or emotional reactions to an object and Behavior Component, the tendency to respond in a certain manner toward an object or activity.

The attitude has several characteristics (Mohsin 1990):

- Attitudes are not inborn; they are learned through experience

- Attitudes can be inferred from the observed antecedent stimulus and the consequent behavior pattern. They are thus, of the nature of an intervening variable and a hypothetical construct

- Attitudes have objective reference; one holds an attitude regarding some object person, or issue. In this respect, they differ from motives or personality traits that have subjective reference.

- Once formed, attitudes are enduring dispositions and are unlikely to change under ordinary conditions.

- From operational point of view, attitudes are manifested in the consistency of responses made to a specific object situation. Because of those characteristics, many researchers have tried a variety of approaches to studying attitudes in an attempt to find the relationship between people's attitude and behavior in different fields such as politics, economics, religion and marketing.

\section{Forming Attitudes and Involvement}

Marks and Kamins (1988) found that attitudes formed as a consequence of product trial are strongly held. Attitudes are formed by all of the four different influences but generally one of them plays a more important role (Hawkins, Best et al. 2004).

Attitudes are formed by three main components (Hawkins, Best and Coney, 2004): Cognitive Component, related to the consumer 's beliefs about a product, which can be generally evaluated; Affective Component, related to the feelings or emotional reactions to an object and Behavior Component, the tendency to respond in a certain manner toward an object or activity.

\section{Consumer's attitude}

Consumer attitude in marketing terms is defined as a general evaluation of a product or service formed over time (Solomon, 2008). Consumer's attitude is the consumers liking, endorsement 
or preference for product attributes, which summarizes the criteria that consumers use to make decisions regarding what products to buy (Kinnear \& Taylor, 1996).

Dr. Lars Perner defines consumer attitude simply as a composite of a consumer's beliefs, feelings, and behavioral intentions toward some object within the context of marketing Lars Perner 2010). A research conducted by Zheng et. al. (2009) concluded that attitudes are associated with future behavior and students with better attitudes with today are more likely to persist and continue learning. Cesar and Cesaradm, (2000) found that there is no positive relationship between a positive attitude towards a service and a higher purchasing behavior, out of 12, only 3 attributes are considered by consumers to evaluate the product. A research conducted by Zheng et al. (2009) concluded that attitudes are associated with future behavior and students with better attitudes with today are more likely to persist and continue learning. According to Katz (1960) Attitude has a significant effect on purchasing a brand and choosing the place for shopping. Moreover, new products emerge in the market or existing products future demand can be predicted by measuring consumer attitude, (Blackwell et. al, 2001).

\section{Dimensions of attitude Cognition}

Cognition is a part of the mental function that deals with the logic. It is concerned with knowledge. Cognition can be defined as the processes an organism uses to organize information. This includes acquiring information (perception), selecting (attention), representing (understanding) and retaining (memory) information, and using it to guide behavior (reasoning and coordination of motor outputs) Bostrom and Sanzber (2009). The cognitive component refers to the knowledge, beliefs, and opinions the person has about the attitude object. The cognitive component is the individual's information and knowledge about an object or concept. Bostromand Sanzberg (2009) depicted cognitive appraisal is always of fundamental importance in determining emotional experience. According to appraisal theory, each distinct emotion is elicited by a specific pattern of appraisal. It is likely that cognitive appraisal is sometimes a consequence rather than a cause of emotional experience.

Ajzen and Fishbein (1980) emphasized the centrality of cognitions as determinants of attitude; several researchers demonstrate the impact of effect on attitude. Fishbein and Ajzen (1975) found that cognitive structure is proposed to mediate the influence of other factors (such as affect) on attitude. This is in line with the discussion of a consumer's cognitive or affective needs (also called psychological motives) such as information learning, entertainment, personal identity, Para social interaction, companionship and escape (Blumler, 1979; Katz et al, 1974; Rubin, 1981; 1983). Hair et al (2000) advocated that measurement objective focus should be on using scale descriptors that reflect the cognitive component of attitude. 


\section{Affection}

Affection is concerned with feeling that deals with emotion. The emotions or feelings associate with a particular product or brand. Chisnall (1975) observes that these feelings may derive from personality traits, motives, social norms, etc. Bodur et al. (2000), suggested that affect influence attitude independently of cognition structure. Some theorists contend that beliefs play a pivotal role in the formation of attitudes while others posit that affect is directly responsible for determining attitudes (Bodur, 2000). This is in line with the discussion of a consumer's cognitive or affective needs (also called psychological motives) such as information learning, entertainment, personal identity, Para-social interaction, companionship and escape (Blumler, 1979; Katz et al, 1974; Rubin, 1981; 1983).

Other authors have argued that non cognitive factors, such as affect, have a significant influence on attitude that is not mediated by the cognitive structure (e.g., Breckler, 1984; Crites, Fabrigar, \& Petty, 1994; Haugtvedt, 1997; Herr, 1995; Miniard\&Barone, 1997; Schwarz, 1997). In addition, Eaglyet.al (1994) used an idiographic rather than a nomothetic approach to measure beliefs and affect. They found that both cognitive structure and affect predict attitude.

\section{Behavioral/Conative}

Behavior is concerned with experiment and judgment. Behavior involves the person's intentions to do something with regard to an attitude object. The behavioral component of an attitude is one's tendency to respond in a certain manner toward an object or activity. Behavior intention scale is the most widely used scale formats in commercial marketing research (Kalwani \& Silk, 1982). Generally, behavior intent scales are found to be good predictors of consumers' choices of frequently purchased and durable consumer products (Siciliano, 1993). Behavior intention scales include purchase intent, attendance intent, shopping intent, usage intent, willingness to refer others etc.

Cesar and Cesaradm (2000) found that there is no positive relationship between a positive attitude towards a service and a higher purchasing behavior, out of 12, only 3 attributes are considered by consumers to evaluate the product: On-time delivery, Food Price and Assortment of Restaurants.

According to the finding of the relationship between attitude and behavior, consumers normally behave with the attempt to protect the environment. Hini, Gendalland Kearns (1995) found the significant linkage between attitudes and behavior even though the strength of the relationship was very weak. The low correspondence between attitudes and behavior may be caused by the reason that the attitudes and behavior are not measured at similar levels of specificity (Dobson, 2007). 


\section{Advertising}

According to American Marketing Association "advertising is any paid form of non-personal presentation and promotion of ideas, goods and services by an identified sponsor

Based on extant literature, determinants such as hedonic, good for economy, product information, values corruption and materialism and consumer benefits consistently indicate strong relationship with consumers' attitude towards advertising (Yang, 2000; Ramaprasad \& Thurwanger, 1998; Pollay \& Mittal, 1993; Bauer \& Greyser, 1968).

Many studies on advertisement and purchase behavior depict positive association. For example study by (Yang at.el, 2000; Ramaprasad \& Thurwanger, 1998; Pollay \& Mittal, 1993; Bauer \& Greyser, 1968) consistently indicates strong relationship with consumers' attitude towards advertising to shape the shopping mall purchasing. Each year marketing managers spend millions of dollars researching consumers 'attitudes toward products and brands, and then spend many more millions trying to influence those attitudes through advertisements, sales promotions, and other types of persuasion (Peter \& Olson, 2005). According to Mehta (2000), consumers 'attitude towards advertising is one of the influential indicators of advertising effectiveness because consumer's cognitive ability towards the advertising are reflected in their thoughts and feelings and subsequently will influence their attitude towards advertising (Mackenzie \& Lutz, 1989).

\section{Conceptual framework}

Depending upon the studies of the previous research, different variables like cognition, affection, behavior, beliefs, perception advertising, and purpose to visit, age, and gender were identified. In this research overall attitude is considered as independent variable, while shopping mall purchasing behavior is the dependent variable and advertising and purpose to visit are considered as moderating variables that affects shopping mall purchasing behavior. The general relationship of these variables is summarized as below:

\section{Figure 2.1: Conceptual framework}

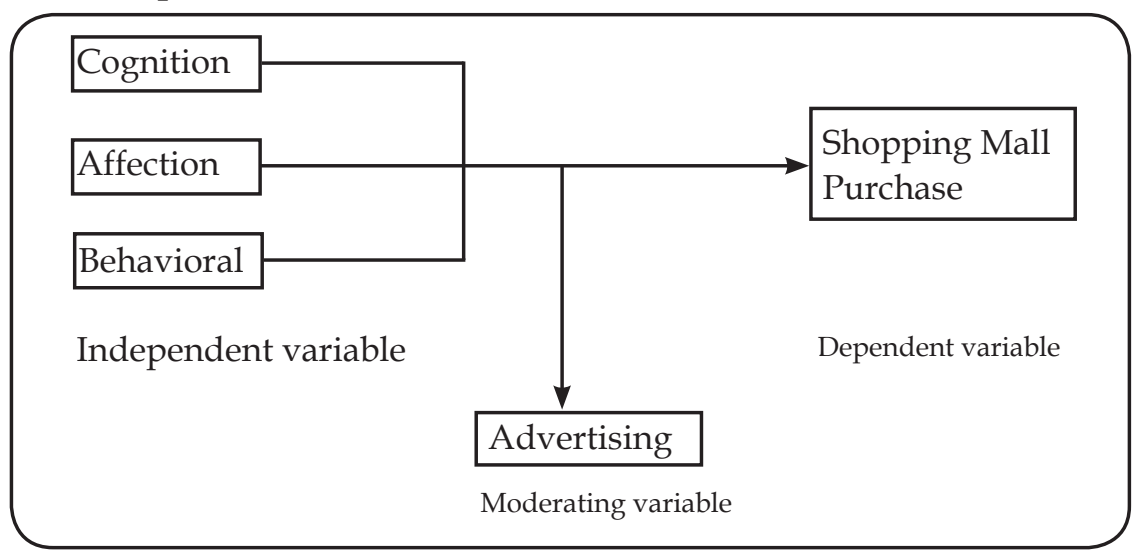




\section{Research Hypotheses}

The study is based on the formulation of the following alternative hypotheses. The research hypotheses are proposed as follows:

H1: There is association between cognition and shopping mall purchasing behavior.

$\mathrm{H} 2$ : There is association between affection and shopping mall purchasing behavior.

H3: There is association between behavior and shopping mall purchasing behavior.

H3: There is an impact of advertising on shopping mall purchasing behavior.

\section{Research methodology}

In this research various methods and process have been applied to answer the problem and accomplish the objectives. It includes research design, nature and sources of data, research approach, research instruments, population and sample and data analysis tools.

\section{Research Design}

The study was based on the descriptive as well as explanatory research design because it has described the demographic distribution of respondents and also shows the relationship between the variables.

\section{Sampling design}

The study had adopted the convenience sampling method. In this survey, 450 questionnaires were distributed to the target samples of different categories of people consisting businessman, service holders, students and others (professor, teacher, lower, nurse) at different area of Kathmandu valley such as Chahabil, Chhetrapati, New road, Baneshwar, Koteshwar and Bhaktapur and Lalitpur.

\section{Data collection process}

The present study is descriptive and analytical in nature. The main aim of this study is to reveal attitude on shopping mall purchasing behavior of consumers in Kathmandu Valley.

In this research, primary data is main sources of information. This research is almost based on primary data to analyze and find out the result of the survey. However secondary data is used at the time of setting objectives, hypotheses formulation and literature review.

Survey method is adopted for collecting primary data as research approach and questionnaire is applied as research instrument to obtain pertinent information from respondents so that it is possible to find out right output. The questionnaire is prepared in 6 points Likert Scale containing strongly disagrees, disagree, moderately disagree, moderately agree, agree and strongly agree. The questionnaire contains 25 questions all are close ended.

This survey is conducted in Kathmandu Valley containing 2.5 million populations (Census 2013) retrieved from retrieved from (www.bossnepal.cm/Popular shopping center in 
Kathmandu) and it focuses those people who have at least little knowledge about shopping mall. They may be potential customers or regular customers or none customers. They are living in Kathmandu Valley even they are from out of Valley. Pilot test had been done conducting with 50 respondents at different areas of Kathmandu valley.

\section{Methods of analysis \\ Reliability Analysis}

The multi-item scales developed above had to be evaluated for their reliability, and validity. Cronbach's Alpha is the most commonly used approach to test reliability of items of questions used in questionnaire. Cronbach's Alpha will be high if the scale items are highly correlated. In the current research, the main assessment method is simple scale measurement for Cronbach Alpha.

Result of Cronbach's Alpha analysis is first examined for reliability and validity of each question in the data set. Gliem and Gliem (2003) opined that the value above 0.7 is considered acceptable and reliable.

All constructs comprising of variables such as overall consumer attitude, advertising, purpose to visit and shopping mall purchase were separately tested to make certain all designed question are reliable. The following table shows the reliability of the items indicating that the scale has good reliability.

Table 1: Reliability results of study variables

\begin{tabular}{|l|l|l|l|l|}
\hline S.N. & Variables & $\begin{array}{l}\text { Cronbach's Alpha } \\
\text { Coefficient }\end{array}$ & $\begin{array}{l}\text { No.of } \\
\text { Items }\end{array}$ & $\begin{array}{l}\text { No. of } \\
\text { Item } \\
\text { Deleted }\end{array}$ \\
\hline 1 & Cognition & 0.650 & 6 & 2 \\
\hline 2 & Affection & 0.712 & 6 & 2 \\
\hline 3 & Behavior & 0.732 & 9 & 0 \\
\hline 4 & Advertising & 0.715 & 4 & 1 \\
\hline 5 & Shopping Mall Purchase & 0.680 & 4 & 0 \\
\hline
\end{tabular}

Cronbach Alpha. However, no question is removed from the advertisement, overall consumer attitude towards shopping mall and shopping mall purchase.

Table 1 shows that Cronbach's alpha of cognition is 0.650 and no of items is 6, Cronbach alpha of affection is 0.712 and no of items is 6 , behavior is 0.732 with no of 9 items advertising is 0.715 with no of 4 items and shopping mall purchase is 0.680 with no of 4 items.. The table shows that Cronbach's alpha of the entire variable are greater than 0.650 . That indicates the consistency of the items taken for the study. 


\section{Descriptive Statistics}

Descriptive statistics is an important statistics tool to compute different values of the variables of a study. In this research, different statistical values are calculated such as mean, standard deviation, standard error, graphs etc. primary data will have been analyzed with the use of it.

\section{Correlation analysis}

Correlation analysis is the statistical tool to identify mutual association between two or more variables. In this research, correlation analysis was conducted to assess the relationship between two variables.

\section{Regression Analysis}

In other to develop models for measuring consumer attitude toward shopping mall and the regression analysis has been applied. Cognition, affection and behavior are taken as independent variables, advertising as moderating variables and shopping mall purchase as the dependent variable.

After analyzing the data, the empirical results are figured out. Based on these results, the discussions are implemented in order to draw findings and conclusions and recommendation for further research.

The following regression equations are regressed to find out the association of attitude and impact of moderating variables on shopping mall purchase:

\section{Regression Model: 1}

$\mathrm{Y}=\alpha+\beta 1 X 1+\beta 2 X 2+\beta 3 X 3+\cdots+$ er.

Where, $\mathrm{a}=$ Constant

$\mathrm{Y}=$ Shopping mall purchase

$\mathrm{X}_{1}=$ Cognition

$X_{2}=$ Affection

$\mathrm{X}_{3}=$ Behavior

$X_{4}=$ Advertising

er $=$ error terms

\section{Result and Discussion}

Present study aims to examine the relationship between and among the shopping mall purchase as dependent with attitude dimensions as independent variable with taking advertisement as moderating variable. 
Major objective of the study is to measure association between attitude dimensions and shopping mall purchase and examine the impact of advertising with shopping mall purchase.

First, the reliability of used measurement scales is tested using Cronbach's alpha coefficient. Altogether thirty four questions have been created taking attitude dimensions, shopping mall purchase advertising in questionnaire.

In the set of questionnaire, twenty five questions are related to attitude dimensions, five questions are related to advertising, and four questions are related to shopping mall purchase.

\section{Demographic status}

The study had collected the demographic information of respondents to know the demographic distribution of shopping male purchase customers. The demographic characteristics includes the gender, profession, age, location. The study also analyzed the types of shopping mall chosen by the consumers.

Table 1: Profile of Respondents by Gender

\begin{tabular}{|l|r|r|}
\hline \multicolumn{1}{|c|}{ Gender } & Frequency & \multicolumn{2}{c|}{ Percent } \\
\hline Male & 185 & 48.2 \\
\hline Female & 199 & 51.8 \\
\hline Total & 384 & 100 \\
\hline
\end{tabular}

Table 1 shows that 48.2 percent of the respondents are male whereas 51.8 are female. The respondents of female are little higher than male.

Table 2: Profile of Respondents by Profession

\begin{tabular}{|l|r|r|}
\hline \multicolumn{1}{|c|}{ Profession } & Frequency & Percent \\
\hline Business & 43 & 11.2 \\
\hline Service & 129 & 33.6 \\
\hline Student & 172 & 44.8 \\
\hline Others & 40 & 10.4 \\
\hline Total & 384 & 100.0 \\
\hline
\end{tabular}

Table 2, the majority of respondents are students accounting for 44.8percent, followed by service holders (33.6) percent, Business people 11.2 percent and respondents in the others category 10.4 percent. 
Table 3: Profile of Respondents by Age

\begin{tabular}{|l|r|r|}
\hline \multicolumn{1}{|c|}{ Age } & Frequency & \multicolumn{2}{c|}{ Percent } \\
\hline 16-21 Years & 130 & 33.9 \\
\hline 22-25 Years & 147 & 38.3 \\
\hline 26-35 Years & 71 & 18.5 \\
\hline Above 35 Years & 36 & 9.4 \\
\hline Total & 384 & 100.0 \\
\hline
\end{tabular}

Table 3, the majority of respondents are 22-25 age group accounting for 38.3percent, followed by 16-21 age group (33.9) percent, 26-35 age group 11.2 percent and respondents in the others category 9.4 percent.

Table 4: Profile of Respondents by Location

\begin{tabular}{|l|r|r|}
\hline \multicolumn{1}{|c|}{ Location } & Frequency & \multicolumn{2}{c|}{ Percent } \\
\hline KTM Valley & 251 & 65.4 \\
\hline Out of KTM valley & 133 & 34.6 \\
\hline Total & 384 & 100 \\
\hline
\end{tabular}

Table 4 shows that 65.4 percent of the respondents are permanent residents of Kathmandu valley and whereas 34.6 are from out of Kathmandu valley temporarily living in Kathmandu valley.

Table 5: Profile of Respondents by Choice of the Shopping Malls

\begin{tabular}{|l|l|l|l|}
\hline Rank & Shopping mall & Frequencies & Percentage \\
\hline 1 & Civil Mall & 187 & 48.7 \\
\hline 2 & City Centre & 76 & 19.8 \\
\hline 3 & People Plaza & 45 & 11.7 \\
\hline 4 & Kathmandu Mall & 31 & 8.1 \\
\hline 5 & United World Trade Centre & 24 & 6.3 \\
\hline 6 & K.L Tower & 16 & 4.2 \\
\hline 7 & Kantipur Mall & 4 & 1.2 \\
\hline
\end{tabular}

Table 5 shows that among the total respondents majority respondents prefer civil mall as their first choice shopping mall (48.7 percent), 19.8 percent are found to prefer City Center and People Plaza 11.7 percent. Kathmandu mall's preference account for 8.1 percent, UWTC (6.3 percent), K.L. Tower (4.2 percent) and Kantipur Mall (1.2 percent).

\section{Descriptive Statistics Analysis}

Mean and standard deviation analysis are used in this study. The higher mean value means more respondents agree to association or impact on shopping mall purchase. When large 
value of standard deviation means that the data being tested is far away from the mean whereas a smaller value means that the tested variable is closer to mean.

Table 6: Summary of Mean and Descriptive Statistics Analysis

\begin{tabular}{|l|l|l|}
\hline Description & Mean & Standard Deviation \\
\hline Cognition & 4.76 & 0.825 \\
\hline Affection & 4.17 & 1.080 \\
\hline Behavioral & 4.41 & 1.078 \\
\hline Advertising & 4.28 & 1.035 \\
\hline Shopping Mall Purchase & 3.90 & 1.078 \\
\hline
\end{tabular}

Table 6 shows the mean and standard deviation of the entire variables under study. All together it includes five variables which consist of 25 questions asked to give their opinions. Mean of all are greater than 3.5. This indicates that respondents tend to agree with the statements.

\section{Correlation Analysis}

Karl Pearson's Correlation coefficient is used to find out the relationship between dependent and independent variables. In this study shopping mall purchase behavior is taken as the dependent variable, overall attitude are independent variable. Similarly, advertising and purpose to visit shopping mall are moderating variables. As correlation is run, there is shown the relation of the all variables on the below table:

Table 7: Correlation Analysis

\begin{tabular}{|l|l|l|l|l|l|}
\hline & Cog & Aff & Beh & Adv & SMPB \\
\hline Cog & 1 & & & & \\
\hline Aff & $.323^{*}$ & 1 & & & \\
\hline Beh & $.386^{*}$ & $.465^{* *}$ & 1 & & \\
\hline Adv & $.315^{* *}$ & $.362^{* *}$ & $.535^{* *}$ & 1 & \\
\hline SMPB & $.137^{* *}$ & $.408^{* *}$ & $.380^{* *}$ & $.309^{* *}$ & 1 \\
\hline
\end{tabular}

Table 7 shows that the relation of shopping mall purchase with cognition, affection, behavior, advertising, purpose to visit and overall consumer attitude has been investigated using Pearson correlation coefficient. The analysis of correlation is obtained and shown here.

Table 7 shows the correlation between shopping mall purchases with its dimension. The correlation between shopping mall purchase behavior and cognition is 0.137 , correlation coefficient of SMP with affection is 0.408 , SMP with behavioral 0.380,SMP with advertisement is 0.309. Similarly correlation between Cog and Aff is 0.323, correlation between Cog and Beh is 0.386, correlation between Cog and Adv is 0.315, Likewise, correlation between Aff and Beh is 0.465 , correlation between Aff and Adv is 0.362. Consequently, correlation between Beh and Advis 0.535. Correlation between SMP with Cog, Aff, Beh and Adv is significant at 99 percent confidence level. ${ }^{*}$ Correlation is significant at the 0.01 level (2-tailed). 
The analysis shows the variables (Cog, Aff, Behand Adv) are significantly correlated with SMP and the variables ( $\mathrm{Cog}$, Aff, Beh and Adv) are significantly correlated with each other at 99 percent confidence level. However, coefficient correlation between Beh and Adv is highest at .535 and correlation coefficient of SMP with cognition is lowest at 0.137 . That is clearly shown that there is higher correlation between Beh and Adv but lower correlation between SMP and cognition.

\section{Test of Mullticolinearity}

The impact of mullticolinearity is a concern for interpreting the regression variable (Hair et.al., 1998). Highly collinear variables can distort the results substantially and thus not generalizable.

Table 8: Mullticolinearity Statistics

\begin{tabular}{|l|l|l|l|}
\hline S. No. & Independent Variables & Tolerance & VIF \\
\hline 1 & Cognition & 0.767 & 1.304 \\
\hline 2 & Affection & 0.676 & 1.480 \\
\hline 3 & Behavioral & 0.570 & 1.753 \\
\hline 4 & Advertising & 0.794 & 1.260 \\
\hline
\end{tabular}

Table 8 show that the tolerance values of all the variables are above 0.10 . Similarly, the VIF value of the independent variables is less than 10 , thus further confirming that multicollinearity problem is not a concern.

\section{Multiple regression analysis}

Multiple regression analysis is the one of the most widely used technique in the data analysis in the social science (Bryan \& Cramer, 2001).The technique can be used to analyze the relationship between a single dependent variable and several independent variables (Tabachnick \& Fidell, 2001). Shopping mall purchase as dependent variable, overall attitude as independent variable and advertising and purpose to visit to shopping mall as moderating variables are taken for different models regression.

\section{Regression- 1}

When Regression- 1 is run, output is obtained on the Table 9 bellow. 
Regression analysis

Table 9: Results of SMP as Dependent and Attitude Dimensions

\begin{tabular}{|c|l|l|l|l|}
\hline & Unstandardized Coefficients & T & Sig. \\
\hline & B & Std. Error & & \\
\hline$($ Constant $)$ & 1.189 & .297 & 3.997 & .000 \\
\hline Cog & -.235 & .059 & -3.953 & .000 \\
\hline Aff & .191 & .064 & 2.972 & .003 \\
\hline Beh & .121 & .068 & 1.790 & .074 \\
\hline Adv & .059 & .050 & 1.177 & .240 \\
\hline R2 & 0.380 & & & \\
\hline F value & 38.443 & & & \\
\hline p value & 0.00 & & & \\
\hline
\end{tabular}

\section{Regression Mode 1:}

$Y=1.189-0.235 X 1+0.191 X 2+0.121 X 3+0.477 X 4+0.059 X 5+0.108 \times 6 \square+$ er

Where $\mathrm{Y}=$ Shopping mall purchase, $\mathrm{X} 1=$ Cognition, $\mathrm{X}=$ Affection, $\mathrm{X} 3=$ Behavioral, $\mathrm{X} 4=$ Overall Consumer Attitude, $\mathrm{X} 5=$ Advertising, $\mathrm{X} 6=$ Purpose to Visit, er $=$ error terms

From the above table $4.9 \mathrm{~F}$ - value of Model 1 is 38.443 which is significant at $5 \%$ level. So the model is fitted linearly.

$\mathrm{R}$ square of this model is 0.380 or $38 \%$ which means $38 \%$ of variation in shopping mall purchase behavior is explained by independent and moderating variables.

Coefficient of cognition variable is -0.235 . That means change in one unit of cognition leads to decrease 0.235 units in shopping mall purchase behavior.

Coefficient of affection is 0.191 . That means change in one unit of affection leads to increase 0.191 units in shopping mall purchase behavior.

Coefficient of overall consumer attitude is 0.477 . That means change in one unit of overall consumer attitude leads to increase 0.477 units in shopping mall purchase.

The coefficients of Aff, Beh are found be positive, whereas the coefficient of Cog is reported to be negative.

\section{Test of hypothesis}

The study has developed the three research hypothesis which are tested statistically and result are presented in Table 13: 
Table 4.13: Summary of Hypothesis Testing

\begin{tabular}{|l|l|l|l|l|l|}
\hline Hypothesis & Relationship & $\begin{array}{l}\text { Standardized } \\
\text { Coefficient }\end{array}$ & t-value & -value & Result \\
\hline H1 & Cognition --- SMP & -.235 & -3.953 & .000 & Supported \\
\hline H2 & Affection --- SMP & .191 & 2.972 & .003 & Supported \\
\hline H3 & Behavioral --- SMP & .121 & 1.790 & .074 & Unsupported \\
\hline H4 & Advertising -- -SMP & .059 & 1.177 & .240 & Unsupported \\
\hline
\end{tabular}

Significant level 5\%, R2=0.380, p-value $=0.00, \quad F=38.443$

Significant level 5\%, R2=0.380, p-value $=0.00, \quad F=38.443$

After testing H1, the result shows that 'There is association between cognition and shopping mall purchase' because $\mathrm{p}$ - Value of cognition coefficient is 0.00 which is significant at $5 \%$ level of significance so hypothesis 1 is accepted.

Similarly, the result shows that 'There is association between affection and shopping mall purchase' because p-Value of affection coefficient is 0.03 which is significant at $5 \%$ level of significance so hypothesis 1 is accepted.

Likewise, the result shows that 'There is no association between behavior and shopping mall purchase' because p-Value of behavior coefficient is 0.74 which is significant at $5 \%$ level of significance so hypothesis 1 is accepted

Finally, the result of $\mathrm{H} 4$ shows that 'There is not impact of advertising on shopping mall purchase' because p-Value of advertising coefficient is 0.240 which is not significant at $5 \%$ level of significance so hypothesis 5 is not accepted.

\section{Major Findings}

The study found that cognition has negative association on shopping mall purchase. Cognition is negatively associated with SMP because of charging high price and expensive product at shopping.

The study found that the affection component has significant impact on shopping mall purchase. Affection component has highly positive association with shopping mall purchase. The study also found that behavior has not association on shopping mall purchase. Cognition is negatively associated with SMP because of charging high price and expensive product at shopping. Advertisement has no significant impact on shopping mall purchasing behavior. The most of the consumers prefer City Center out of other shopping malls in Kathmandu Valley. 


\section{Discussions}

The literature of cognition, affection and behavior on shopping mall purchasing could not be found out in previous study therefore it could not discuss on attitude dimensions on shopping mall purchase behavior. However this study found that advertisement does not have significant impact in shopping mall purchase behavior. It was not in line with the earlier studies by Yang, 2000; Ramaprasad \& Thurwanger, 1998; Pollay \& Mittal, 1993; Bauer \& Greyser concluded that the effect of advertisement and purchase behavior depicted positive association. Similarly, this study found that 'purpose to visit' has affected the shopping mall purchase behavior. Similar finding was reported by an earlier study of Bhardwajet et al. (2011).

The correlation between advertisement and purchase behavior are observed to be positive and it was in line with the earlier studies by Yang, 2000; Ramaprasad \& Thurwanger, 1998; Pollay \& Mittal, 1993; Bauer \& Greyser concluded that the effect of advertisement and purchase behavior depicted positive association.

\section{Conclusion and implications}

\section{Conclusion}

From the above analysis, results can be concluded as

Shopping Mall attracts the urban consumers but not to rural customers in purchasing behavior due to lack of knowledge that they usually think that there is expensive. The consumers like to go to the shopping small to have full of fun and entertainment with different facilities such as food court, cinema, lift, parking, Children Park, meeting space and so on. And they fell happy to choose and get varieties of goods from under one roof. The shopping Malls are in the growing phase and the customer is being familiar with the needs of shopping mall to the extension of the shopping pattern in shopping malls. So, the focus has to be there on the extent of shopping malls considering rather than experience and reactions. Advertising does not affect the shopping Mall purchasing behavior. Its not effective for shopping mall. However publicity, sales promotion, words of mouth and personal selling are important to develop the warm relation to existing customers and attract potential customers. City Center is the most popular shopping center/mall in Kathmandu valley Consumers are the most valuable component in marketing of goods and services in any business area. Present study is concentrated with the identifying those consumers attitude dimension in purchasing their needs in shopping malls in Nepalese context. However, most of the earlier researchers explored that different dimensions of consumer attitude such as overall consumer attitude has significant association with shopping mall purchase in the Indian context. Although shopping mall purchase is a well-established construct in consumer behavior research, applications are relatively scarce in current marketing research projects. The reasons are diverse. First, shopping mall purchase is often as merely a transitory phenomenon. Second, problems of measurement as well as difficulties in administering data collection often get in the way of empirically addressing shopping mall purchase. The current study builds upon recent contribution to the measurement of shopping mall purchase. 
Research results figured out that consumer attitudes differ in social and economic backgrounds of customers. Therefore, defining customer categories for age, income, education, etc. and constituting different marketing strategies for each category is believed to help shopping malls to gain competitive advantage.

\section{Implications}

Shopping Mall in Kathmandu valley should consider all dimensions of consumers' attitude in planning and implementation.

Shopping Mall should reduce the advertising costs but better to emphasize the publicity and public relation, sales promotion as well.

\section{Academic implications}

This research contributes in the body of knowledge to conduct research in the context of Nepal. The advertisement has not sufficient result to support shopping mall purchase in the present research. Advertising is itself brand to attract customers towards shopping mall and most of the consumer are not advertising friendly and they have less access to shopping mall to fulfill their purchase requirements. So, this search provides a path for the further research in the area of shopping mall purchase for further studies.

\section{Future avenues}

There is a need for additional research into the relationship between overall attitude and shopping mall purchase. Future research may take into accounts different variables such education, age, gender, profession, geographical concentration and education could be considered as moderating variables to the impact of them on shopping mall purchase behavior. Further study may be conducted on consumer attitude toward organic product, eco car etc. to check the implication of the variables under this study. 


\section{References}

Allport, G. W. (1935). Attitudes in Murchison C. (Ed.), Handbook of social psychology (pp. 798844). Worcester, MA: Clark University Press.

Bauer, R. A. \& Greyser, S. A. (1968) Advertising in America: The consumer view. (Unpublished Graduate dissertation). Boston, MA: Harvard University.

Bauer, R.A., \& Greyser, S. A. (1968). Advertising in America: The consumer view. (Unpublished Graduate dissertation). Boston, MA: Harvard University.

Bhardwajet, S. et. al.(2011), Perception of Consumers towards Shopping Mall- A Case Study With Reference To Aligarh and Mathura City , VSRD-IJBMR, Vol. 1 (5), 2011, 321334

Blackwell et. al, (2001). Jati Kasuma et. at, (2015), Antecedents of Sconsumer behavior and foreign product evaluation among consumer Journal of Scientific Research and Development 2(14):19-25Universiti Teknologi MARA

Brackett, L. K., \& Carr, B. N. (2001). Cyberspace advertising vs. other media: Consumer vs. mature student attitudes. Journal of Advertising Research, 41(5), pp. 23-33.

Brackett, L. K., \& Carr, B. N. (2001). Cyberspace advertising vs. other media: Consumer vs. mature student attitudes. Journal of Advertising Research, 41(5), 23-32.

Bryan, A., \& Cramer, D. (2001). Quantitative data analysis with SPSS release 10 for window: A guide for social scientists. East Essex: Rout ledge.

Cesar \& Cesaradm, (2000). Impact of Consumer Attitude in Predicting Purchasing Behaviour.

Frat, A. F., \& Venkatesh, A. (1993). Postmodernity: The age of marketing. International Journal of Research in Marketing 10 (3): 227-249.

Gliem \& Gliem (2003), Meta-analysis of Alpha Cronbach 's Coefficient. Journal of Consumer Research, University of Chicago Press.

Hair. J.F., Anderson, R.E., Tatham, R.L., \& Black, W.C (1998). Multivariate data analysis" ( $^{\text {th }}$ Ed.). London, Prentice Hall.

Hawkins, Del I., Best, R. J., \& Coney, K. A. (2004). Consumer behavior: Building market solomon, M. R. consumer behavior, buying, having and being strategy, Pearson Prentice Hall. $6^{\text {th }}$ Ed.

Hawkins, Del I., Best, R. J., Coney, K. A. (2004). Consumer Behavior: Building Market Strategy. McGraw-Hill/Irwin.9th Ed. 
Hini, D., Gendall, P., \& Kearns, Z. (1995). The Link between Environmental Attitudes and behavior. Marketing Bulletin.

Hoyer, W. D., MacInnis, D. J, (2001). Consumer behaviour, Houghton Mifflin Company. 2 nd Ed. 2001.

Huang, J. H. et al. (2004). Consumer attitude toward gray market goods, International Marketing 21(6):598-614

J.Paul Peter \& Jerry C. Olson (2005) Consumer behavior and market strategy.7th.ed.McGrawHill international edition

Jen-Hung, Huang; Lee, Bruce C Y; Ho, Shu Hsun International Marketing Review; 2004; 21, 6; ABI/INFORM Global.pg.598

Joseph A. Gliem Rosemary R. Gliem (2003) Calculating, Interpreting, and Reporting Cronbach's Alpha Reliability Coefficient for Likert-Type Scales- Midwest Research to Practice Conference in Adult, Continuing, and Community Education

Katz, D. (1960). The functional approach to the study of attitudes, Public opinion quarterly, pp. 163-204.

Katz, E., Blumler, J. G., \& Gurevitch, M. (1974).Utilization of Mass Communication by the Individual. In Blumler, J. G. and Katz, E. (Ed.), the Uses of Mass Communications: Current Perspectives on Gratifications Research. Beverly Hills, CA: Sage Publications, 1974, pp. 19-32.

Kinnear, T. C and Taylor, J. 1996). Marketing Research - And Applied Approach. $5^{\text {th }}$ Ed.

Leo, P.J., \& Phillipe, J. (2002). Retail centers: location and consumer's satisfaction, the service industries journal, 22(1), 122-146

MacKenzie, S. B. \& Lutz, R. L. (1989).An empirical examination of the structural antecedents of attitude toward the ad in an advertising pretesting context. Journal of Marketing, 53, 48- 65 .

Marks, LI and Kamins, M.A. (1988).The use of Product Sampling and Advertising. Journal of Marketing Research, August, 266 - 81.

Mehta, A. (2000). Advertising attitudes and advertising effectiveness. Journal of Advertising Research, 40(3), 67-72.

Mohsin, (1990). Wei He, S. X. (2011). A study of Chinese consumers' attitudes toward Volvo cars 
Mohsin, 1990 S, Wei He, S. X. (2011). The study of Chinese Consumer Attitude towards Volvo Car: Master's Thesis in International Management. A study of Chinese consumers' attitudes toward Volvo cars

Peper,P. \&Jerry C. Olson, J. (2005). Consumer behavior and market strategy.7th .ed. McGrawHill international edition

Perner, L. (2010). Consumer behavior: the psychology of marketing. Retrieved October 2, 2010, from http://www.consumerpsychologist.com/

Petty, R. E., Unnava, H. R., Stratham, A.J. (1991). Theories of attitude change, Handbook of consumer Behaviour, Prentice-hall. 21.

Pickens, J. (2005). Attitudes and Perceptions- Leadership and Management http:// healthadmin. jbpub.com/Borkowski/chapter3.pdf (pp. 43-76).

Pine, B. J., and J. H. Glimore. (1999). the experience economy: Work is theater $\mathcal{E}$ every business a stage. Cambridge, MA: Harvard University Press.

Pollay, R. W. \& Mittal, B. (1993). Here's the beef: Factors, determinants and segments in consumer criticism of advertising. Journal of Marketing, 57(7), 99-114.

Pride, W. M. and Ferrell, O.C. (1991). Marketing: Concepts and Strategies, Houghton Mifflin Company. 7 Ed.

Ramaprasad, J. \& Thurwanger, M. L. (1998). South Asian students attitudes toward and beliefs about advertising: Measuring across cultures. Paper presented at the AEJMC Annual Conference on International Communication Division, Baltimore, MD.

Sharma, S.K.R. (2012). Customer Attitude towards Shopping Malls in Mumbai: International Journal of Trade and Commerce, vol. 2, No.2, pp. 269-280.

Solomon, 2008 understanding-consumer-attitudes- Marketography Market, Measure, Repeat

Solomon, M. R. 2004. Consumer Behaviour, Buying, Having and Being, Pearson Prentice Hall. 6 th Ed. 2004.

Solomon, M.R. 2008. Understanding-consumer-attitudes- Marketography Market, Measure, Repeat

Tabachnick, B.G., \& Fidell, L.S. (2001). Using Multivariate statistics (4th fd.). London, Pearson Education Company. 
Yang, C. C. (2000).Taiwanese students' attitudes towards and beliefs about advertising. Journal of Marketing Communication, 6,

Zheng et. al. (2009), Lynne D. Roberts et.al Student Attitudes toward Learning Analytics in Higher Education: "The Fitbit Version of the Learning World" Front. Psychol. 